\title{
In vitro assessment of cytotoxic, apoptotic and genotoxic effects of metformin
}

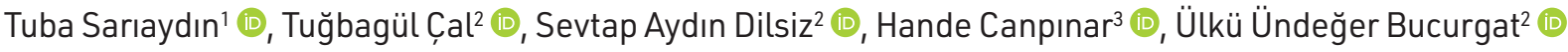 \\ 'University of Health Sciences Ankara Training and Research Hospital, Clinics of Emergency Medicine, Ankara, Turkey \\ ${ }^{2}$ Hacettepe University, Department of Pharmaceutical Toxicology, Faculty of Pharmacy, Ankara, Turkey \\ ${ }^{3}$ Hacettepe University, Institute of Cancer Department of Basic Oncology, Ankara, Turkey
}

ORCID IDs of the authors: T.S. 0000-0002-0374-3200; T.C.. 0000-0002-1476-0233; S.A.D. 0000-0002-6368-2745;

H.C. 0000-0002-8973-6289; Ü.Ü.B. 0000-0002-6692-0366

Cite this article as: Sariaydin, T., Cal, T., Aydin Dilsiz, S., Canpinar, H., \& Undeger Bucurgat, U. (2021). In vitro assessment of cytotoxic, apoptotic and genotoxic effects of metformin. Istanbul Journal of Pharmacy, 51(2), 167-174.

\begin{abstract}
Background and Aims: Recent studies have shown the anticancer properties of metformin, which is widely used in diabetes mellitus. The possible mechanisms of anticancer effects of metformin have not been fully elucidated. We aimed to investigate the cytotoxic, genotoxic, and apoptotic effects of metformin in HepG2 and HeLa cells.

Methods: The cytotoxicity, genotoxicity, and apoptotoic effects were determined by MTT method, Comet assay, and FACS assay, respectively.

Results: Metformin significantly decreased cell viability above 4 and $32 \mathrm{mM}$ in HepG2 and HeLa cells, respectively, for $48 \mathrm{~h}$. The IC50 values were $57.3 \mathrm{mM}$ (HepG2) and $76.9 \mathrm{mM}$ (HeLa). Metformin (5-1000 $\mu \mathrm{M}$ ) alone did not increase DNA damage in all cells. It did not change oxidative DNA damage in HepG2 cells but induced oxidative DNA damage in HeLa cells. HepG2 cells treated with only $32 \mathrm{mM}$ metformin revealed $10 \%$ apoptosis. G0/G1 phase accumulation was statistically higher in the cells treated with 4, 8, and $64 \mathrm{mM}$ metformin $(91 \%, 99 \%$, and $97 \%$ respectively) than in (-) control ( $80 \%)$. HeLa cells revealed apoptosis of $30 \%, 39 \%, 27 \%$ at 4,32 , and $64 \mathrm{mM}$ concentrations, respectively. The results implicate that the inhibition of HepG2 cell viability may be due to the arrest of cell cycle in G0/G1 phase and apoptosis, whereas apoptotic response is mainly responsible for the cytotoxicity of metformin in HeLa cells.

Conclusion: Metformin may not induce DNA damage at non-cytotoxic high doses and lead to apoptosis, even if compatible with previous data. This study provides important information that metformin may play an essential role in apoptosis and cell cycle progression in carcinoma cell lines, which can explain the anticancer effects of metformin, but further studies are needed to support these results.
\end{abstract}

Keywords: Metformin, genotoxicity, apoptosis, HepG2 cells, HeLa cells

\section{INTRODUCTION}

Despite advancements in diagnosis and medical care, cancer remains as the leading reason for death worldwide. While the most common cancers in males are prostate, lung and bronchus and colorectal; the most common cancers in females are breast, lung and bronchus and colorectal (Siegel, Miller \& Jemal, 2019).

Antidiabetic drugs are known to influence cancer progression, as high glucose level is a risk factor for both cancer and diabe- tes. Metformin (1,1- dimethylbiguanide) is a product of French lilac (Galega officinalis L.). It is an oral biguanide functioning as a hypoglycemic agent (Kamarudin, Sarker, Zhou, \& Parhar, 2019). This drug lowering the blood glucose level is widely used for the treatment of type 2 diabetes. It is responsible for the activation of the energy sensor AMP-activated protein kinase (AMPK), and it has been associated with the inhibition of glucose production in primary hepatocytes (Kim et al., 2019). It is well-described in the literature that metformin suppresses 
carcinogenesis by inhibiting the transformative and hyperproliferative processes with anti-angiogenesis, radio-chemosensitizer and anti-metabolic effects (Salani, Del Rio, Marini, Sambuceti, Cordera, \& Maggi, 2014; Leone, Di Gennaro, Bruzzese, Avallone, \& Budillon, 2014; Jalving et al., 2010).

Cell checkpoints and apoptosis, which are important molecular pathways in anticancer effect, are well known for playing a vital role in regulating growth, development, and immune response, therefore removing cancerous cells. The avoidance of apoptosis is an important hallmark of cancer; thus, the ability to induce apoptosis and suppress cell growth is a promising therapeutic approach in cancer research. Although chemotherapeutics can be used to achieve this, their use is associated with high levels of toxicity. In several studies, the anticancer effect of metformin has been the focus of attention. Usefulness of metformin in reducing the risk for diabetes related cancers as well as breast cancer, cervix cancer, pancreas cancer, prostate cancer and colorectal cancer have been investigated in numerous studies (Kamarudin, Sarker, Zhou, \& Parhar, 2019; Kim et al., 2019; Lopez-Bonet, et al., 2019; Donadon, Balbi, Casarin, Vario, \& Alberti, 2008; Giovannucci \& Michaud, 2007; Dombrowski, Mathieu, \& Evert, 2006).

The antitumor effects of metformin on Hela and HepG2 cells and the mechanisms underlying apoptosis, and their cell cycle regulation remain elusive. There are conflicting results regarding the effects of metformin on genotoxicity. It seems that the mechanistic studies on anticancer effects are required to evaluate how metformin affects the apoptotic pathways and genotoxicity together. In this study, we aimed to investigate the cytotoxic, genotoxic and apoptotic effects of metformin on human hepatoma cells (HepG2) and cervical cancer cells (HeLa).

\section{MATERIALS AND METHODS}

\section{Chemicals}

Metformin was obtained from Sigma Aldrich (St. Louis, USA). Also 3-(4,5-dimethylthiazol-2-yl)-2,5-diphenyltetrazolium bromide (MTT), dimethyl sulfoxide (DMSO), Dulbecco's modified Eagle's medium (DMEM), ethanol, ethidium bromide ( $E t B r)$, ethylenediamine tetra acetic acid disodium salt dihydrate ( $\mathrm{Na}_{2}$-EDTA), fetal bovine serum (FBS), hydrogen peroxide (35\%) $\left(\mathrm{H}_{2} \mathrm{O}_{2}\right)$, low melting point agarose (LMA), methanol, $\mathrm{N}$-lauroyl sarcosinate, normal melting point agarose (NMA), penicillinstreptomycin, phosphate buffered saline (PBS), propidium iodide, Roswell Park Memorial Institute Medium (RPMI 1640), sodium chloride $(\mathrm{NaCl})$, sodium hydroxide $(\mathrm{NaOH})$, Tris, Triton X-100, and trypsin- EDTA were purchased from Sigma Aldrich (St Louis, USA). Cisplatin was acquired from Koçak Farma ${ }^{\circledast}$ (Istanbul, Turkey).

\section{Cell culture}

The human cell lines (HepG2 and HeLa) used in our study were obtained from American Type Culture Collection (ATCC) (Rockville, MD, USA). The HeLa cells were cultured in $500 \mathrm{ml} \mathrm{RPMl}$ 1640 (RPMI 1640 medium containing L-Glutamine) with $50 \mathrm{~mL}$ FBS (10\%) and $5 \mathrm{~mL}$ penicillin/streptomycin (1\%). The HepG2 cells were grown in $500 \mathrm{~mL}$ DMEM (medium containing L-Glu- tamine and $5 \mathrm{mM}(1 \mathrm{~g} / \mathrm{L})$ glucose) supplemented with $50 \mathrm{~mL}$ of FBS (10\%) and $5 \mathrm{~mL}$ of penicillin/streptomycin (1\%).

The mediums were stored at $+4^{\circ} \mathrm{C}$ and cells were removed by trypsinization. Cells were incubated in $5 \% \mathrm{CO}_{2}$ and $95 \%$ humidity at $37^{\circ} \mathrm{C}$.

\section{Cell viability assay}

MTT assay was performed to determine the viability of HepG2 and HeLa cells treated with a wide range of doses of metformin. Non-cytotoxic doses and cytotoxic doses of metformin were selected for the evaluation of genotoxicity and apoptosis, respectively, after the determination of cytotoxicity. A 0.5 $\mathrm{M}$ metformin stock solution prepared freshly in medium was used after filtered through a $0.2 \mu \mathrm{M}$ millipore filter. The MTT assay is a colorimetric assay by measuring colored formazan product to assessing cell metabolic activity. The cultured cells were plated into 96-well plates with $1 \times 10^{4} \mathrm{cells}$ /well. After $24 \mathrm{~h}$, the cells were incubated with a wide range of doses of metformin (0.5-64 mM) for $48 \mathrm{~h}$. Substance solutions were discarded at the end of the incubation period, $90 \mu \mathrm{L}$ of medium and 10 $\mu \mathrm{L}$ of $5 \mathrm{mg} / \mathrm{mL}$ MTT stock solution were added to each well (final MTT concentration $0.5 \mathrm{mg} / \mathrm{mL}$ ) and were allowed to incubate for $4 \mathrm{~h}$. To dissolve the formazan crystals formed in the wells, $100 \mu \mathrm{L}$ of DMSO was added to each well. The absorbance values of the samples at $570 \mathrm{~nm}$ wavelength were measured in the spectrophotometer.

Cytotoxicity was calculated by the percentage of the ratio between treated and untreated (control) cells (\% cell viability) using eq. (1). $A_{\text {blank }}$ and $A_{\text {sample }} /$ control were indicating the absorbance of blank and absorbances of samples or control, respectively. $I C_{50}$ values of the compounds and the concentration reducing the cell viability of treated cells by $50 \%$ with reference to the control (untreated cells), were determined from the dose-response curves. Four independent assays were performed. The medium was used as negative control and the medium containing $20 \mu \mathrm{M}$ cisplatin as positive control.

Percentage of cell viability (\% cell viability)

$=($ Asamples-Ablank) / (Acontrol-Ablank) x 100 (1)

\section{Analyses of the cell cycle and apoptosis}

Cells were planted in 12-well plates with $4 \times 10^{4}$ cells in each well and incubated for $24 \mathrm{~h}$ to adapt to the culture environment in $5 \% \mathrm{CO}_{2}$ at $37^{\circ} \mathrm{C}$. At the end of the incubation period, appropriate volumes of metformin solutions at 0.5-64 mM concentrations were added to each well and the cells were incubated for $48 \mathrm{~h}$. Then the cells were washed 2 times with 2 $\mathrm{ml}$ of cold PBS and $400 \mu \mathrm{L}$ trypsin-EDTA solution was added to each well. Then, $50 \mu \mathrm{L}$ RNAse and $70 \mu \mathrm{L}$ propidium iodide were added to HepG2 and HeLa cells, then incubated for 15 min in the dark at room temperature. Stained HepG2 and HeLa cells were analyzed by flow cytometry (BD FACSCalibur).

\section{Analyses of genotoxicity (Comet assay)}

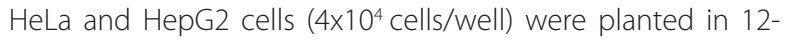
well plates. The cells were incubated with the non-cytotoxic doses of metformin (5-1000 $\mu \mathrm{M})$ for $48 \mathrm{~h}$. The Trypan Blue dye 
exclusion test was applied to determine the viable cells and the cell viability was above $80 \%$ in the comet method. After the pretreatment of metformin for $48 \mathrm{~h}$, oxidative damage was induced by replacing the medium with PBS containing $50 \mu \mathrm{M}$ $\mathrm{H}_{2} \mathrm{O}_{2}$ and then incubating for 5 min on ice to assess the effect against oxidative DNA damage. At the end of the incubation period to examine the effects of DNA damage, the cells were trypsinized with trypsin-EDTA and washed with PBS. The cell suspension $(50 \mu \mathrm{L})$ mixed with $100 \mu \mathrm{L}$ 0.5\% LMPA melted at $37^{\circ} \mathrm{C} \pm 0.5^{\circ} \mathrm{C}$ was spread on agar-coated slides previously immersed in 1\% NMPA solution and the coverslip was closed. Then they were placed into the electrophoresis solution for 20 min, at $25 \mathrm{~V}$ and $300 \mathrm{~mA}$. After electrophoresis, the slides were stained with $50 \mu \mathrm{L}$ ethidium bromide $(20 \mu \mathrm{g} / \mathrm{mL}) .100$ random cell analyzes were performed using fluorescence microscope (Leica) for each sample by using the comet computerized imaging system (Comet Analysis Software, version 3.0 Kinetic Imaging). The medium was used as a negative control and $50 \mu \mathrm{M}$ $\mathrm{H}_{2} \mathrm{O}_{2}$ was used as a positive control.

\section{Statistical analysis}

All of the experiments were performed three or four times. The data are presented as means \pm standard deviation. Whether the data was normally distributed or not, it was evaluated using the Kolmogorov-Smirnov test and histograms. The differences between the groups were determined by one-way analysis of variance (ANOVA), LSD test. In all analyzes, statistical significance level was accepted as $p<0.05$.

\section{RESULTS}

\section{Effects of metformin on cell viability}

We used MTT assay to determine the cytotoxic effect of metformin on HepG2 and HeLa cells treated with a wide range doses of metformin.

It was observed that metformin did not have a significant cytotoxic effect in HepG2 cells at the concentration range of 0.5-2 $\mathrm{mM}$ after $48 \mathrm{~h}$ incubation when compared to negative control (PBS), but it produced a statistically significant decrease in cell viability at concentrations of $4 \mathrm{mM}$ and above in a dose-dependent manner $(p<0.05)$ (Figure 1$). I C_{50}$ was found to be 57.3 $\mathrm{mM}$ in HepG2 cells exposed to metformin for $48 \mathrm{~h}$.

Metformin did not produce a significant cytotoxic effect in HeLa cells at the concentration range of 0.5-16 mM after 48 $\mathrm{h}$ incubation when compared to negative control (PBS), but it significantly reduced cell viability at $32 \mathrm{mM}$ and $64 \mathrm{mM}$ concentrations in a dose-dependent manner $(p<0.05)$ (Figure 2). $\mathrm{IC}_{50}$ value was found to be $76.9 \mathrm{mM}$ in HeLa cells exposed to metformin for $48 \mathrm{~h}$.

\section{Effects of metformin on cell cycle and apoptosis}

The changes in cell cycle progression were evaluated using the flow cytometry method to determine the growth inhibition in the metformin treated HepG2 cells.

In cell cycle analysis with HepG2 cells, 10\% apoptosis was observed in the cell population at a concentration of only $32 \mathrm{mM}$ (Figure 3). The statistically significant increases in the accumulation of G0/G1 phase at 4, 8, and 64 mM concentrations (91\%,

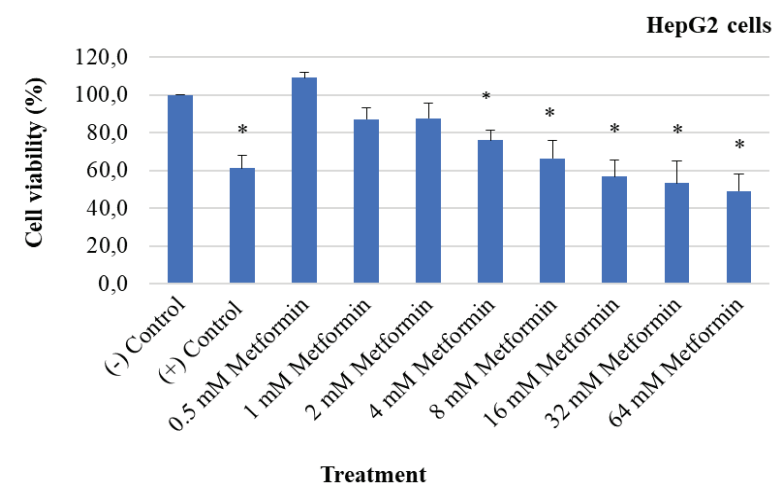

Figure 1. Effect of metformin on HepG2 cell viability at $24 \mathrm{~h}$ exposure. Values were given as the mean \pm standard deviation. ${ }^{*} p<0.05$, statistically different from negative control (PBS).

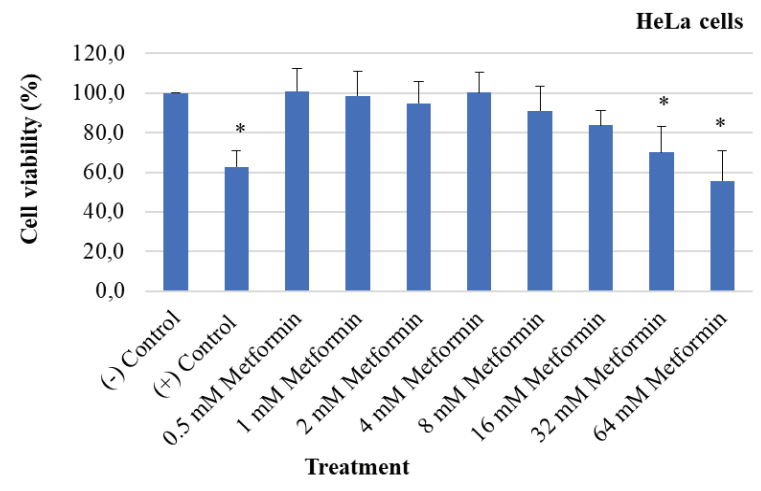

Figure 2. Effect of metformin on HeLa cell viability at $24 \mathrm{~h}$ exposure. Values were given as the mean \pm standard deviation. ${ }^{*} p<0.05$, statistically different from negative control (PBS).
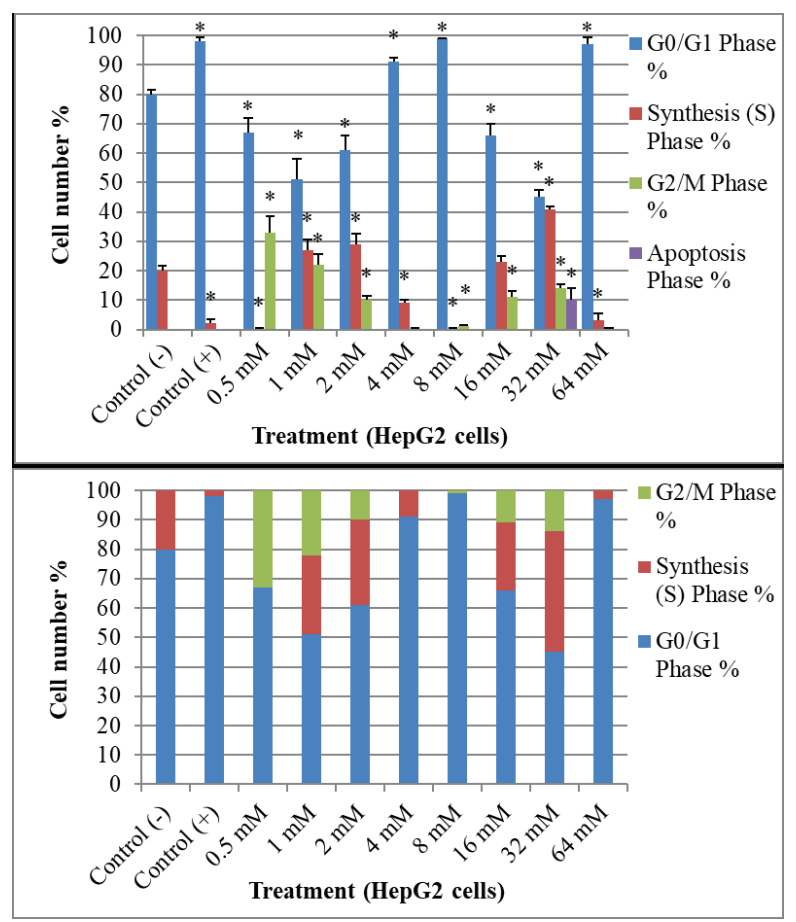

Figure 3. Effect of metformin on apoptosis and cell cycle in HepG2 cells. Values were given as the mean \pm standard deviation. ${ }^{*} p<0.05$, statistically different from negative control (PBS). 
$99 \%$, and $97 \%$, respectively) were found when compared to the (-) control (80\%). Although the accumulation was detected in the G0/G1 phase, proliferation was observed in the cells. The accumulations in $\mathrm{S}$ phase at other concentrations of 1,2 , and $32 \mathrm{mM}$ were found to be $27 \%, 29 \%$, and $41 \%$, respectively, which were statistically higher than (-) control (20\%). The accumulation in the G2/M phase were found to be 33\%, 22\%, $10 \%, 11 \%$, and $14 \%$ at the concentrations of $0.5,1,2,16$ and $32 \mathrm{mM}$, respectively, which were statistically higher than the (-) control (0\%).

In the cell cycle analysis with HeLa cells, 30\%, 39\%, and 27\% apoptosis were observed at 4, 32, and $64 \mathrm{mM}$ concentrations of metformin, respectively. A statistical increase in the accumulation of G0/G1 phase was found at only $2 \mathrm{mM}$ of metformin (88\%) when compared to (-) control (78\%), but proliferation occurred at this concentration. The accumulation in $\mathrm{S}$ phase at 16 and $32 \mathrm{mM}$ concentrations ( $47 \%$ and $26 \%$, respectively) were found to be statistically higher than the (-) control (22\%). On the other hand, the accumulation in the G2/M phase was only observed at the concentration of $0.5 \mathrm{mM}$ metformin (18\%) (Figure 4).

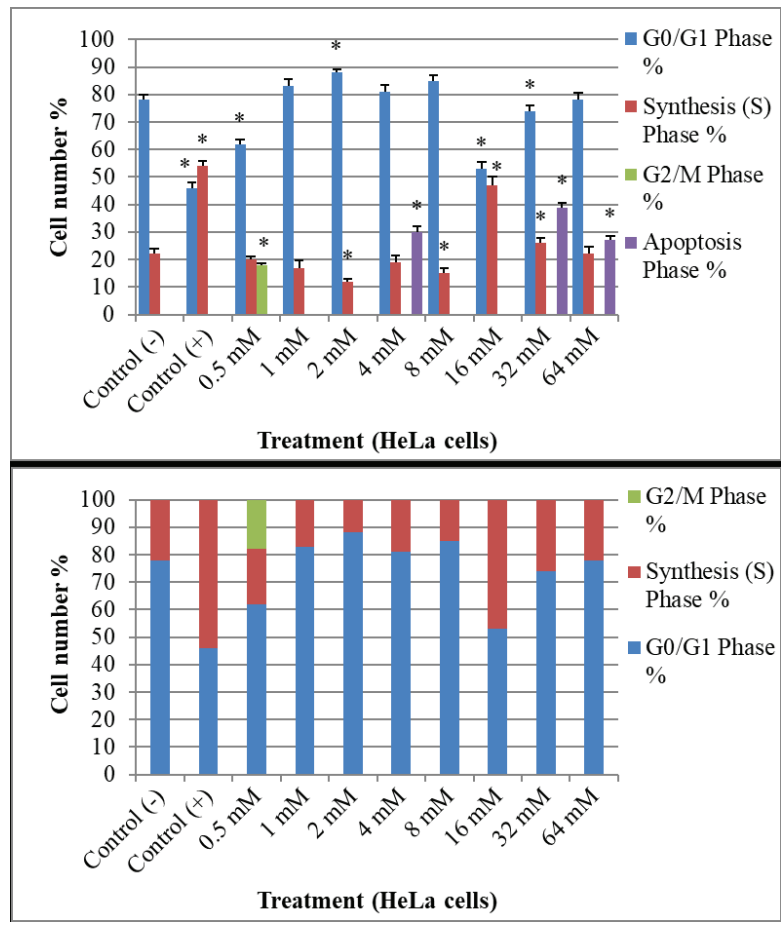

Figure 4. Effect of metformin on apoptosis and cell cycle in HeLa cells. Values were given as the mean \pm standard deviation. ${ }^{*} \mathrm{p}<0.05$, statistically different from negative control (PBS).

\section{Effects of metformin on the genotoxicity}

The comet method was used to evaluate the genotoxic effect of metformin, and DNA tail intensity, DNA tail moment, and DNA tail migration were analyzed as DNA damage indicators. At the end of the $48 \mathrm{~h}$ incubation period, it was determined that metformin alone had no genotoxic effect on HepG2 and HeLa cells. Metformin also did not change $\mathrm{H}_{2} \mathrm{O}_{2}$-induced DNA damage in HepG2 cells, however it increased oxidative DNA damage in HeLa cells (Figures 5 and 6).

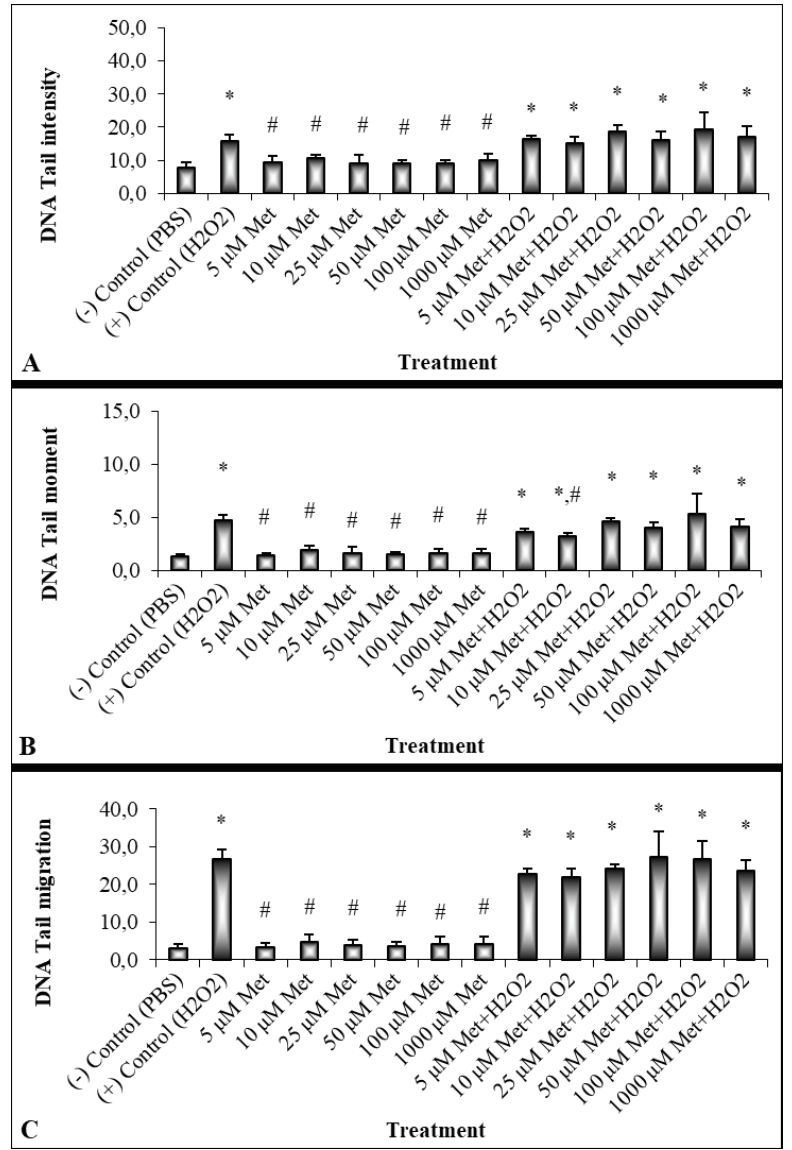

Figure 5. Genotoxicity of metformin in HepG2 cells. DNA damage expressed as DNA tail intensity (A), DNA tail moment (B), DNA tail migration (C) in HepG2 cells. Met= metformin. Values were given as the mean \pm standard deviation. ${ }^{*} p<0.05$, statistically different from negative control (PBS). \#p $<0.05$, statistically different from positive control $\left(50 \mathrm{MM} \mathrm{H}_{2} \mathrm{O}_{2}\right)$.

\section{DISCUSSION}

Day by day cancer has become one of the most serious mortalities and morbidity causes in the world. Therefore, cancer treatment has begun to come to the fore. Current chemotherapeutic drugs cannot effectively control tumor progression. Resistance to drug inhibiting therapy is common, which increases the trend towards new approaches. New therapy initiatives are needed to increase the overall survival rate of cancer patients. Recently, some studies have provided preliminary evidence that metformin can reduce the risk of cancer and improve prognosis in diabetic patients. For this purpose, in vitro and in vivo studies have become widespread in various types of cancer related to metformin. The results are sometimes contradictory in the studies conducted. Some studies show that metformin has an inhibitory effect on the growth of various human cancer cells. However, data on whether these growth-inhibiting effects alone cause arrest of cell apoptosis or alter the cell cycle are not well known. Although some of these studies suggest several possible mechanisms, the detailed molecular basis is largely unknown. On the other hand, many studies have shown that metformin inhibits cell proliferation by causing apoptosis and can lead the cell to death (Will, Pa- 


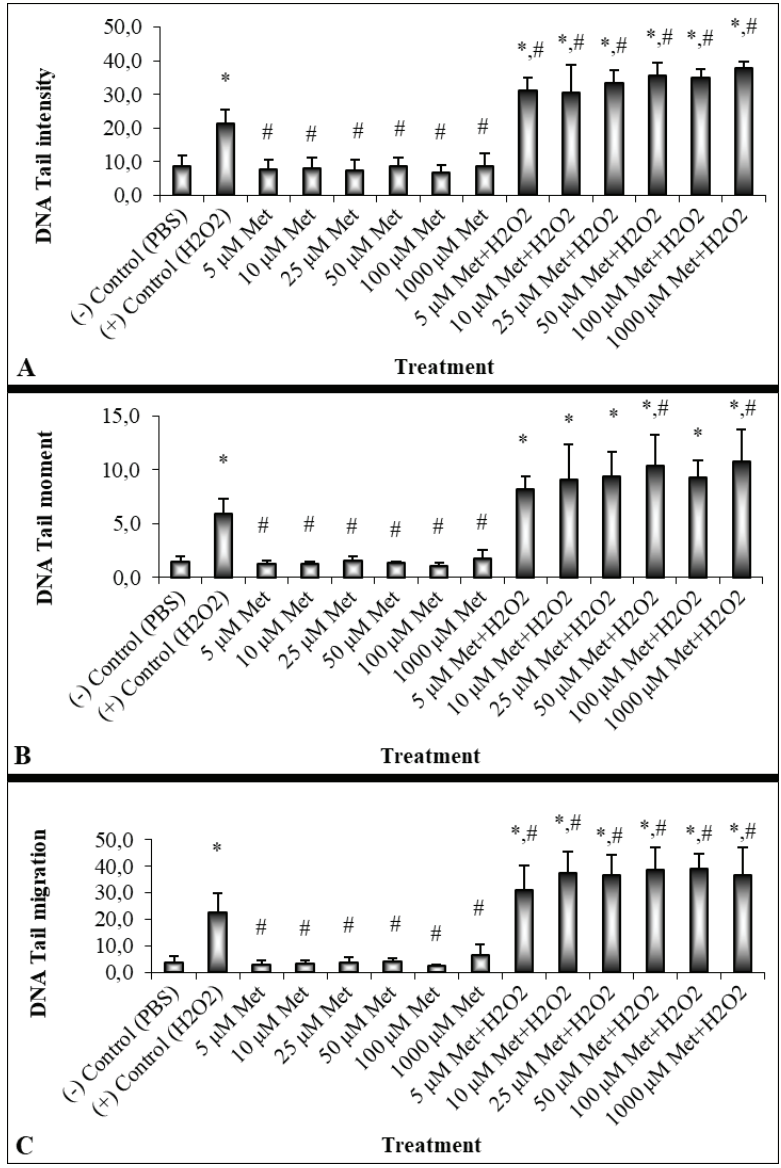

Figure 6. Genotoxicity of metformin in HeLa cells. DNA damage expressed as DNA tail intensity (A), DNA tail moment (B), DNA tail migration $(C)$ in HeLa cells. Met= metformin. Values were given as the mean \pm standard deviation. ${ }^{*} p<0.05$, statistically different from negative control (PBS). \#p $<0.05$, statistically different from positive control (50 $\mu \mathrm{M} \mathrm{H}_{2} \mathrm{O}_{2}$ )

laniappan, Peegel, Kayampilly, \& Menon, 2012; Colquhoun et al., 2012; Zhuang \& Miskimins, 2011).

Our data shows that the $\mathrm{IC}_{50}$ value was determined to be $57.3 \mathrm{mM}$ for HepG2 cells at $48 \mathrm{~h}$ exposure. It was observed that metformin did not produce a significant cytotoxic effect in HepG2 cells in the concentration range of 0.5-2 mM, but it caused a statistically significant decrease in cell viability at the concentrations of $4 \mathrm{mM}$ and above in a dose-dependent manner. Research on cell viability in HepG2 cells has also shown that metformin reduces dose-dependent cell viability, in accordance with our study (Zhang et al., 2018; Sun et al., 2016; Cai et al., 2013).

In our study, we found that metformin alone did not induce DNA damage and also did not change oxidative DNA damage in all studied non-cytotoxic concentrations (5-1000 $\mu \mathrm{M})$ in HepG2 cells ( $p>0.05$ ). These results suggest that metformin does not bring about DNA damage in HepG2 cells. In a study, metformin was shown to reduce ROS accumulation, DNA damage and mutations in experimental systems containing mitochondrial toxins (Algire et al., 2012). Although metformin causes a decrease in DNA damage, various mechanisms are emphasized, and the decrease in ROS level has been revealed in many studies conducted in different cell lines (Piro, Rabuazzo, Renis, \& Purello, 2012; Kane et al., 2010; Ouslimani, Peynet, Bonnefont-Rousselot, Therond, Legrand, \& Beaudeux, 2005).

DNA damage formation, inhibition of transcription and replication, and induction of apoptosis may produce different results that mediate cell death. Increased DNA damage and accumulation of these damages can lead to cell death or pause in different phases of the cell cycle. In the literature, it was observed that metformin induced apoptosis different cell lines including HepG2 cells. After longer exposures (3-14 days), metformin $(\geq 40 \mu \mathrm{M})$ induced a dose-and time-dependent increase in the number of apoptotic $\beta$-cells (Kefas et al., 2004). It was found that metformin did not induce apoptosis but blocked cell cycle in G0/G1 in human prostate cancer cells (DU145, PC-3 and LNCaP cancer cells). This blockade was accompanied by a strong decrease of cyclin D1 protein level, pRb phosphorylation and an increase in p27kip protein expression (Ben Sahra et al., 2008). Metformin suppressed cell growth and induced apoptosis in a dose-dependent manner in hepatocellular carcinoma cells (Saito et al., 2013). In our study, metformin significantly reduced cell viability above $4 \mathrm{mM}$ in HepG2 cells in a dose-dependent manner $(p<0.05)$. We found that the accumulations in the G0/G1 phase at the concentrations of $4 \mathrm{mM}$, $8 \mathrm{mM}$ and $64 \mathrm{mM}$ metformin and the accumulations in the $\mathrm{S}$ phase statistically increased when compared to the negative control. Metformin caused 10\% apoptosis in HepG2 cells at a concentration of $32 \mathrm{mM}$. It seems that metformin induced significant growth inhibition of HepG2 cells through the induction of G0/G1 phase and S phase cell-cycle arrest (Kefas et al., 2004; Ben Sahra et al., 2008; Saito et al., 2013).

In our results, it was observed that metformin did not have a significant cytotoxic effect in HeLa cells in a range of 0.5-16 $\mathrm{mM}$ concentration, but significantly reduced cell viability at 32 $\mathrm{mM}$ and $64 \mathrm{mM}$ concentrations in a dose-dependent manner $(p<0.05)$. We also found that metformin alone did not reveal DNA damage at the non-cytotoxic concentrations (5-1000 $\mu M)(p>0.05)$, however it induced oxidative DNA damage in HeLa cells at all studied doses $(p<0.05)$. In the cell cycle analysis with HeLa cells, 30\%, 39\%, 27\% of apoptosis were observed in the cell population at concentrations of $4 \mathrm{mM}, 32 \mathrm{mM}$ and 64 $\mathrm{mM}$, respectively. Few studies relating the effects of metformin on HeLa cells viability have similarly shown that metformin reduces cell viability and induces apoptosis (Xia et al., 2017; Tyszka-Czochara, Konieczny, \& Majka, 2017; Tyszka-Czochara, Bukowska-Strakova, \& Majka, 2017).

Different $I C_{50}$ metformin levels reported in previous studies appear to be due to differences in cell types, cytotoxicity tests, and treatment times. The effects of metformin on the proliferation of esophageal squamous cell carcinoma cells (ESCC, EC109, and EC9706) treated with different concentrations were investigated for $24 \mathrm{~h}$ to $72 \mathrm{~h}$ using MTT assay. Cell viability decreased depending on the dose and time, consistent with our study. For $24 \mathrm{~h}$, the significant decrease in cell viability was observed only at $20 \mathrm{mM}$ metformin (about $\mathrm{IC}_{50}$ ). A dramatic suppression in the growth of the EC109 cell lines 
was observed after metformin (20 mM) treatment for $72 \mathrm{~h}$ (Cai et al., 2015).

Metformin inhibited the proliferation of esophageal carcinoma cell lines (T.T, KYSE30 and KYSE70 cells) as shown by WST8 test, an MTT-like test. Metformin led to a dose-dependent and strong inhibition of cell proliferation. In KYSE70 cells, although $5 \mathrm{mM}$ metformin did not affect the proliferation of cancer cells, treatment with $10 \mathrm{mM}$ metformin inhibited the proliferation of cells. The highest dose $(10 \mathrm{mM})$ of metformin significantly increased the cell proliferation for $24 \mathrm{~h}$ (Kobayashi et al., 2013).

Zhang et al. investigated the effects of metformin and curcumin on proliferation, apoptosis, invasion, metastasis and angiogenesis of hepatocellular carcinoma cells in vitro and in vivo. The $\mathrm{IC}_{50}$ values of metformin were $53.72 \mathrm{mM}, 23.46 \mathrm{mM}$, $8.52 \mathrm{mM}$ for $24 \mathrm{~h}, 48 \mathrm{~h}$ and $72 \mathrm{~h}$, respectively, in HepG2 cells by CCK-8 assay. $10 \mathrm{mM}$ metformin also significantly increased the apoptotic effects of curcumin about two times in HepG2 cells. Metformin was also found to be involved in down-regulation of MMP2 and MMP9 (well-known proliferation/metastasis proteins) (Zhang et al., 2018).

Yudhani et al. reported that metformin enhanced the antiproliferative effect of cisplatin in cervical carcinoma cell lines. Treatment of $10 \mathrm{mM}$ metformin showed inhibition of HeLa cell proliferation and $\mathrm{IC}_{50}$ was reported to be $60 \mathrm{mM}$ by MTT assay, which was like our result. Combination of $30 \mathrm{mM}$ metformin and $5 \mu \mathrm{M}$ cisplatin indicated the strongest anti-proliferative effect on HeLa cells (Yudhani, Pesik, \& Indarto, 2016).

Wang et al. investigated the anti-myeloma effects of metformin in myeloma cells (RPMI8226 and U266). Cell viability was assessed with CCK8 cytotoxicity assay. The cell viability decreased with increasing concentrations of metformin and with increasing duration of treatment. The $\mathrm{IC}_{50}$ of metformin was reported to be $20.2 \mathrm{mM}$ and $17.9 \mathrm{mM}$ in RPMI8226 cells and U266 cells, respectively, for $48 \mathrm{~h}$ (Wang et al., 2018).

Xia et al. reported that metformin inhibited cervical carcinoma cells (HeLa and SiHa) proliferation, cervical cancer xenograft growth, expression of PCNA, p-PI3K and p-Akt. It induced apoptosis and caused cancer cell cycle arrest and also upregulated the expression of DDR-1 and p53. Metformin also regulated the mRNA and protein expression of MICA and HSP70 on the surface of human cervical cancer cells via the PI3K/ Akt pathway, enhancing NK cell cytotoxicity. Metformin was reported to inhibit cervical carcinoma cells proliferation in a time-dependent manner for $24 \mathrm{~h}, 48 \mathrm{~h}$ and $72 \mathrm{~h}$ by using CCK8 test, a MTT-like test. The $\mathrm{IC}_{50}$ values of metformin for $72 \mathrm{~h}$ were $25.13 \mathrm{mM}$ and $19.43 \mathrm{mM}$ in HeLa and SiHa cells, respectively, which were about three times lower than our results. The apoptosis ratio of the cells treated with $20 \mathrm{mM}$ metformin for $48 \mathrm{~h}$ were found to be increased from 11.61 to $39.04 \%$ and 5.69 to $12.31 \%$ for HeLa cells and SiHa cells, respectively. The percentage of G0/G1 phase increased and the percentage of $S$ phase cells decreased when HeLa and SiHa cells treated with 20 mM metformin for 48 h (Xia, Liu, He, Cai, \& Chen, 2020).
Studies on the cell cycle analysis in its anticancer effect has shown that other different pathways may also be responsible for this effect. It was reported that metformin was effective in blocking the cell cycle in $\mathrm{GO} / \mathrm{G} 1$, but not in the induction of apoptosis in human prostate cancer cells (DU145, PC-3 and LN$\mathrm{CaP})$ treated with metformin ( 1 and $5 \mathrm{mM}$ ) (38-54\% decrease in cell viability, in a dose-dependent manner). It inhibited cyclin D1 expression and pRb phosphorylation independently of the sensor pathway AMPK (Ben Sahra et al., 2008). It was observed that metformin $(10 \mathrm{mM})$ blocked the cell cycle in G0/G1 for $24 \mathrm{~h}$. This blockade was accompanied by a strong decrease of G1 cyclins, especially cyclin D1, as well as decreases in cyclindependent kinase (Cdk)4, Cdk6 and phosphorylated retinoblastoma protein (Rb). In addition, the expression of miRNAs was markedly altered with the treatment of metformin in vitro. Metformin inhibited the growth of esophageal carcinoma cells, and this inhibition may have involved reductions in cyclin D1, Cdk4 and Cdk6 (Kobayashi et al., 2013).

Wang et al. revealed the accumulation of cells in the G0/G1 phase, while the fraction of cells in the $S$ phase decreased in the cells treated with $5 \mathrm{mM}$ and $20 \mathrm{mM}$ metformin for $24 \mathrm{~h}$. They concluded that metformin effectively inhibited the cell proliferation, which is associated with the induction of autophagy and G0/G1 cell cycle arrest, but not apoptosis. They suggested that the molecular mechanism of metformin is also involved in AMPK activation (Wang et al., 2018). Kheirandish, Mahboobi, HYazdanparast, Kamal \& Kamal (2018) stated that AMPK-dependent (decreases in folate level, c-Myc and NF- KB; increases in p53 phosphorylation ) and AMPK-independent (decreases in ROS and cyclin D1; increases in mTORC1) pathways may be responsible for the anticancer effects of metformin. Metformin also decreases both pro-inflammatory cytokines and improves the immune response to cancer cells.

Cell cycle progression, involved in cell division and replication, can be restricted under conditions such as DNA replication error, nutrient depletion, DNA damage and low growth factor. Cell cycle regulatory functions are usually impaired in cancer cells. Therefore, the improvement in cell cycle progression might be an effective strategy for the treatment of carcinomas. Cyclin, cyclin-dependent kinases (CDKs) and CDK inhibitors (CDKIs) in the G1 phase interact with each other to regulate cell-cycle transitions and cell division. It was reported that the anti-proliferative action of metformin on esophageal squamous carcinoma cell lines (ESCC) was partially mediated by AMPK. Moreover, it was observed that metformin induced G0/ G1 phase arrest accompanied by the up-regulation of $\mathrm{p} 21^{\mathrm{CIP1} 1}$ and p $27^{\mathrm{KPI} 1}$. The results indicate that metformin may inhibit carcinoma cell growth via causing cell cycle arrest and delaying tumorigenesis (Cai et al., 2015).

In some reports it has been concluded that metformin might induce DNA damage, however some of reports indicated no genotoxic effects (Janjetovic et al., 2011; Attia, Helal, \& Alhaider, 2009; Onaran, Guven, Ozdas, Kanigur, \& Vehid, 2006). In one study, metformin was found to increase DNA damage at the dose of $114.4 \mu \mathrm{g} / \mathrm{mL}(882,6 \mu \mathrm{M})$ in Chinese hamster ovary cells for $24 \mathrm{~h}$ using comet assay (Amador, Longo, Lacava, Dórea, \& 
Almeida Santos, 2012). In another study, it was reported that metformin did not reduce hydroperoxide-induced DNA damage at the concentrations ranging from $10 \mu \mathrm{M}$ to $50 \mu \mathrm{M}$ for $1 \mathrm{~h}$ treatment time in the human lymphocytes using comet assay (Onaran et al., 2006). However, metformin was found to reduce age- and oxidative stress-related accumulation of DNA damage marked by $\mathrm{YH} 2 \mathrm{AX}$ foci and 8-oxo-dG in intestinal stem cells from Drosophila midgut treated with $5 \mathrm{mM}$ metformin in food media for 6 days (Na et al., 2013).

In our study, metformin was found to be responsible for the changes in the cell cycle arrest, with differences between HepG2 and HeLa cells. In HepG2 cells, the G0/G1 phase accumulation may be mainly responsible for the regulation of cell proliferation. Moreover, G2/M phase accumulation was also shown, being greater at lower doses (33\% and 22\% for 0.5 and $1 \mathrm{mM}$, respectively). It is assumed that the G0/G1 phase and the G2/M phase play a role against cytotoxicity and maintaining cell viability, respectively, in HepG2 cells, whereas in HeLa cells, apoptosis rather than the G0/G1 and G2/M phases seems to be primarily responsible for the effect of metformin on cell proliferation.

\section{CONCLUSION}

In recent studies, metformin has been shown to be a promising anticancer drug. The number of studies on combinations and effects of metformin with various anticancer drugs is increasing. Our study showed that metformin decreased cell viability in a dose-dependent manner and it did not induce DNA damage in HepG2 and HeLa cells at non-cytotoxic doses, but did lead to a significant change in apoptosis at high doses. In conclusion, we suggest that metformin may not cause DNA damage but lead to apoptosis. This study provides important information that metformin may play an essential role in the apoptosis and cell cycle progression in carcinoma cell lines, which can explain the anticancer effect of metformin. Although there are various studies in the literature on which pathways metformin produce these effects, it is not certain yet. For this reason, further studies are needed to clarify these pathways.

Peer-review: Externally peer-reviewed.

Author contributions: Conception/Design of Study- T.S., B.Ü.B.; Data Acquisition- T.S., T.Ç., H.C., B.Ü.B.; Data Analysis/Interpretation- T.S., T.Ç., H.C., S.A.D.,B.Ü.B.; Drafting Manuscript- T.S., S.A.D., B.Ü.B.; Critical Revision of Manuscript- T.S., B.Ü.B.; Final Approval and Accountability- T.S., T.Ç., H.C., S.A.D.,B.Ü.B.

Conflict of Interest: The authors have no conflict of interest to declare.

Financial Disclosure: This work was supported by the Hacettepe University Scientific Research Projects Coordination Unit (THD-201713153).

\section{REFERENCES}

- $\quad$ Algire, C., Moiseeva, O., Deschênes-Simard, X., Amrein, L., Petruccelli, L., Birman, E., Viollet, B., Ferbeyre, G. \& Pollak, M. N. (2012). Metformin reduces endogenous reactive oxygen species and associated DNA damage. Cancer Prevention Research, 5(4), 536-543.
Amador, R. R., Longo, J. P. F., Lacava, Z.G., Dórea, J. G. \& Almeida Santos, M. F. M. (2012). Metformin (dimethyl-biguanide) induced DNA damage in mammalian cells. Genetics and Molecular Biology, 35(1), 153-158.

- $\quad$ Attia, S. M., Helal, G. K., \& Alhaider, A. A. (2009). Assessment of genomic instability in mormal and diabetic rats treated with metformin. Chemico-Biological Interactions, 180(2), 296-304.

- Ben Sahra, I., Laurent, K., Loubat, A., Giorgetti-Peraldi, S., Colosetti, P., Auberger, P., Tanti, J. F., Le Marchand-Brustel, Y., \& Bost, F. (2008). The antidiabetic drug metformin exerts an antitumoral effect in vitro and in vivo through a decrease of cyclin D1 level. Oncogene, 27, 3576-3586.

Cai, X., Hu, X., Cai, B., Wang, Q., Li, Y., Tan, X. ... Jing, X. (2013). Metformin suppresses hepatocellular carcinoma cell growth through induction of cell cycle G1/G0 phase arrest and p21 CIP and p27KIP expression and downregulation of cyclin D1 in vitro and in vivo. Oncology Reports, 30(5), 2449-2457.

- Cai, X., Hu, X., Tan, X., Cheng, W., Wang, Q., Chen, X., Guan, Y., Chen, C., \& Jing, X. (2015). Metformin Induced AMPK Activation, G0/G1 Phase Cell Cycle Arrest and the Inhibition of Growth of Esophageal Squamous Cell Carcinomas In Vitro and In Vivo. PLoS One, 10(7), e0133349.

- Colquhoun, A. J., Venier, N. A., Vandersluis, A. D., Besla, R., Sugar, L. M., Kiss, A. ...Venkateswaran, V. (2012). Metformin enhances the antiproliferative and apoptotic effect of bicalutamide in prostate cancer. Prostate Cancer and Prostatic Diseases, 15(4), 346-352.

Dombrowski, F., Mathieu, C., \& Evert, M. (2006). Hepatocellular neoplasms induced by low-number pancreatic islet transplants in autoimmune diabetic BB/Pfd rats. Cancer Research, 66(3), 18331843.

Donadon, V., Balbi, M., Casarin, P., Vario, A., \& Alberti, A. (2008). Association between hepatocellular carcinoma and type 2 diabetes mellitus in Italy: Potential role of insulin. World Journal of Gastroenterology, 14(37), 5695-5700.

- Giovannucci, E. \& Michaud, D. (2007). The role of obesity and related metabolic disturbances in cancers of the colon, prostate, and pancreas. Gastroenterology, 132(6), 2208-2225.

- Jalving, M., Gietema, J. A., Lefrandt, J. D., de Jong, S., Reyners, A. K. L., Gans, R. O. B., \& de Vries, E. G. E. (2010). Metformin: taking away the candy for cancer? European Journal of Cancer, 46(13), 2369-2380.

- Janjetovic, K., Harhaji-Trajkovic, L., Misirkic-Marjanovic, M., Vucicevic, L., Stevanovic, D., Zogovic, N., Sumarac-Dumanovic, M., Micic, D., \& Trajkovic, V. (2011). In vitro and in vivo anti-melanoma action of metformin. European Journal of Pharmacology, 668, 373382.

- $\quad$ Kamarudin, M. N. A., Sarker, M. M. R., Zhou, J. R., \& Parhar, I. (2019). Metformin in colorectal cancer: molecular mechanism, preclinical and clinical aspects. Journal of Experimental \& Clinical Cancer Research, 38(1), 491-514.

- Kane, D. A., Andersen, E. J., Price, J. W., Woodlief, T. L., Lin, C. T., Bikman, B. T., Cortright, R. N., \& Neufer, P. D. (2010). Metformin selectively attenuates mitochondrial $\mathrm{H} 2 \mathrm{O} 2$ emission without affecting respiratory capacity in skeletal muscle of obese rats. Free Radical Biology \& Medicine, 49, 1082-1087.

- Kefas, B. A., Cai, Y., Kerckhofs, K., Ling, Z., Marten, G., Heimberg, H., Pipeleers, D., \& de Casteele, M. V. (2004). Metformin induced stimulation of AMP-activated protein kinase in beta-cells impairs their glucose responsiveness and can lead to apoptosis. Biochemical Pharmacology, 68, 409-416.,

Kheirandish, M., Mahboobi, H., Yazdanparast, M., Kamal, W., \& Kamal, M.A. (2018). Anti-cancer effects of metformin: Recent evidences for its role in prevention and treatment of cancer. Current Drug Metabolism, 19(9), 793-797. 
- $\quad$ Kim, M.Y., Kim, Y.S., Kim, M., Choi, M.Y., Roh, G.S., Lee, D.H. ... Choi, W.S. (2019). Metformin inhibits cervical cancer cell proliferation via decreased AMPK O-GlcNAcylation. Animal Cells and Systems, 23(4), 302-309.

- Kobayashi, M., Kato, K., Iwama, H., Fujihara S., Nishiyama, N., Mimura, S. ...Masaki, T. (2013). Antitumor effect of metformin in esophageal cancer: in vitro study. International Journal of Oncology, 42(2), 517-24.

- Leone, A., Di Gennaro, E., Bruzzese, F., Avallone, A., \& Budillon, A. (2014). New perspective for an old antidiabetic drug: Metformin as anticancer agent. Cancer Treatment and Research, 159, 355-376.

- Lopez-Bonet E, Buxó M, Cuyàs E, Pernas, S., Dorca, J., Álvarez, I. . . . Menendez J.A. (2019). Neoadjuvant metformin added to systemic therapy decreases the proliferative capacity of residual breast cancer. Journal of Clinical Medicine, 8(12), 2180-2197.

- $\quad$ Na, H. J., Park, J. S., Pyo, J.H., Lee, S. H., Jeon, H. J., Kim, Y. S., \& Yoo, M. A. (2013). Mechanism of metformin: Inhibition of DNA damage and proliferative activity in Drosophila midgut stem cell. Mechanisms of Ageing and Development, 134(9), 381-390.

- Onaran, I., Guven, G. S., Ozdas, S. B., Kanigur, G., \& Vehid, S. (2006). Metformin does not prevent DNA damage in lymphocytes despite its antioxidant properties against cumene hydro-peroxideinduced oxidative stress. Mutation Research, 611, 1-8.

- Ouslimani, N., Peynet, J., Bonnefont-Rousselot, D., Therond, P., Legrand, A., \& Beaudeux, J. L. (2005). Metformin decreases intracellular production of reactive oxygen species in aortic endothelial cells. Metabolism, 54, 829-834.

- $\quad$ Piro, S., Rabuazzo, A. M., Renis, M. \& Purello, F. (2012). Effects of metformin on oxidative stress, adenine nucleotides balance and glucose-induced insulin release impaired by chronic FFA exposure in rat pancreatic islets. Journal of Endocrinological Investigation, 35(5), 504-510.

- Saito, T., Chiba, T., Yuki, K., Zen, Y., Oshima, M., Koide, S. ... Yokosuka, O. (2013). Metformin, a diabetes drug, eliminates tumor-initiating hepatocellular carcinoma cells. PloS One. 8(7), e70010.

- Salani, B., Del Rio, A., Marini, C., Sambuceti, G., Cordera, R., \& Maggi, D. (2014). Metformin, cancer and glucose metabolism. EndocrineRelated Cancer, 21(6), 461-471.

- $\quad$ Siegel, R. L., Miller, K. D., \& Jemal, A. (2019). Cancer statistics. CA: a Cancer Journal for Clinicians, 69(1), 7-34.
Sun, Y., Tao, C., Huang, X., He, H., Shi, H., Zhang, Q., \& Wu, H. (2016). Metformin induces apoptosis of human hepatocellular carcinoma HepG2 cells by activating an AMPK/p53/miR23a/FOXA1 pathway. OncoTargets and Therapy, 9, 2845-2853.

Tyszka-Czochara, M., Bukowska-Strakova, K., \& Majka, M. (2017). Metformin and caffeic acid regulate metabolic reprogramming in human cervical carcinoma SiHa/HTB35 cells and augment anticancer activity of Cisplatin via cell cycle regulation. Food and Chemical Toxicology, 106, 260-272.

- Tyszka-Czochara, M., Konieczny, P., \& Majka, M. (2017). Caffeic acid expands antitumor effect of metformin in human metastatic cervical carcinoma HTB-34 cells: implications of AMPK activation and impairment of fatty acids de novo biosynthesis. International Journal of Molecular Sciences, 18(2), 462-478.

- $\quad$ Wang, Y., Xu, W., Yan, Z., Zhao, W., Mi, J., Li, J., \& Yan, H. (2018). Metformin induces autophagy and G0/G1 phase cell cycle arrest in myeloma by targeting the AMPK/mTORC1 and mTORC2 pathways. Journal of Experimental \& Clinical Cancer Research, 37(1), 63.

- Will, M.A., Palaniappan, M., Peegel, H., Kayampilly, P., \& Menon, K.M. (2012). Metformin: Direct inhibition of rat ovarian theca-interstitial cell proliferation. Fertility and Sterility, 98(1), 207-214.

- $\quad$ Xia, C., Chen, R., Chen, J., Qi, Q., Pan, Y., Du, L., Xiao, G., \& Jiang, S. (2017). Combining metformin and nelfinavir exhibits synergistic effects against the growth of human cervical cancer cells and xenograft in nude mice. Scientific Reports, 7, 43373.

- $\quad$ Xia, C., Liu, C., He, Z., Cai, Y. \& Chen, J. (2020). Metformin inhibits cervical cancer cell proliferation by modulating PI3K/Aktinduced major histocompatibility complex class I-related chain A gene expression. Journal of Experimental \& Clinical Cancer Research, 39(1), 127.

- Yudhani, R. D., Pesik, R. N. \& Indarto, D. (2016). Metformin enhances anti-proliferative effect of cisplatin in cervical cancer cell line. Indonesian Journal of Clinical Pharmacy, 5(2), 75-83.

Zhang, H. H., Zhang, Y., Cheng, Y. N., Gong, F. L., Cao, Z. Q., Yu, L. G., \& Guo X. L. (2018). Metformin in combination with curcumin inhibits the growth, metastasis, and angiogenesis of hepatocellular carcinoma in vitro and in vivo. Molecular Carcinogenesis, 57(1), 44-56.

- Zhuang, Y., \& Miskimins, W. K. (2011). Metformin induces both caspase-dependent and poly (ADP-ribose) polymerase-dependent cell death in breast cancer cells. Molecular Cancer Research, 9(5), 603-615. 